\title{
In vivo and ex vivo impact of nutritional xenobiotics - acrylamide and sodium nitrates - on plasma antioxidant properties
}

\author{
Wpływ wybranych ksenobiotyków pokarmowych - akrylamidu i azotanów - \\ na właściwości antyoksydacyjne osocza $\mathrm{w}$ warunkach in vivo oraz ex vivo \\ Anna Rorbach-Dolata1 (D) , Ewa Żurawska-Płaksej² (D) ,Zofia Marchewka' ${ }^{1}$, Agnieszka Piwowar' ${ }^{1}$ \\ ${ }^{1}$ Department of Toxicology, Faculty of Pharmacy with Division of Laboratory Diagnostics, Wroclaw Medical University \\ 2Department of Pharmaceutical Biochemistry, Faculty of Pharmacy with Division of Laboratory Diagnostics, \\ Wroclaw Medical University
}

\begin{abstract}
INTRODUCTION: The thiol (SH) groups present in human blood plasma play an important role in the oxidative/antioxidative homeostasis of the organism. They are susceptible to the adverse actions of different exo- and endogenous factors. Chronic exposure to different xenobiotics, e.g. nitrogen-containing compounds commonly occurring in food, is especially important. The aim of this study was to investigate the effect of acrylamide (ACR) and sodium nitrates (SN) - (V) and (III) - on the plasma antioxidant properties, as reflected by changes in the SH group levels.

MATERIAL AND METHODS: The concentration of SH groups was measured by Ellman's method in blood plasma derived from 62 young people (in vivo model; time to), and after 1 hour of blood plasma incubation with appropriate ACR and SN (III) concentrations (ex vivo model; time $t_{1}$ ). The concentrations used corresponded with their daily intake (DIA - daily intake of acrylamide, and DIN - daily intake of sodium nitrates (V) and (III), respectively), estimated on the basis of a nutritional questionnaire.

RESULTS: In both models, acrylamide and nitrates caused a significant decrease in SH group concentrations, but ACR induced stronger changes. The women consumed a greater amount of these nitrogen-containing compounds compared to the men, probably due to their different dietary habits.

CONCLUSIONS: The obtained results indicate that these nitrogen-containing xenobiotics are important agents lowering antioxidative plasma potential, hence their intake should be controlled.
\end{abstract}

\section{KEY WORDS}

acrylamide, sodium nitrate (III) and (V), daily intake, thiol groups, antioxidant potential

\section{STRESZCZENIE}

WSTĘP: Grupy tiolowe (SH) obecne w osoczu krwi odgrywają ważną rolę w oksydacyjno-antyoksydacyjnej homeostazie organizmu. Są one podatne na niekorzystne działanie różnych czynników egzo- i endogennych. Szczególnie istotnym problemem jest długotrwałe narażenie na różne ksenobiotyki, np. związki zawierające azot, powszechnie występujące w żywności. Celem naszych badań była ocena wpływu akrylamidu (acrylamide - ACR) i azotanu sodu (sodium nitrate - SN) - (V) i (III) - na właściwości przeciwutleniające osocza poprzez pomiar stężenia grup SH.

$\begin{array}{llll}\text { Received: } 10.07 .2018 \quad \text { Revised: 09.04.2019 Accepted: } 25.04 .2019 & \text { Published online: } 13.08 .2019\end{array}$

Address for correspondence: Dr n. farm. Ewa Żurawska-Płaksej, Katedra i Zakład Biochemii Farmaceutycznej, Wydział Farmaceutyczny z Oddziałem Analityki Medycznej, Uniwersytet Medyczny im. Piastów Śląskich we Wrocławiu, ul. Borowska 211 A, 50-556 Wrocław, Polska, tel. + 48717840468 , e-mail: ewa.zurawska-plaksej@umed.wroc.pl

Copyright $\odot$ Śląski Uniwersytet Medyczny w Katowicach

www.annales.sum.edu.pl 
MATERIAŁ I METODY: Stężenie grup SH w osoczu uzyskanym od 62 młodych osób (model in vivo; czas to) oraz w próbkach poddanych godzinnej inkubacji z odpowiednim stężeniem ACR i SN (III) (model ex vivo; czas $\mathrm{t}_{1}$ ) mierzono metodą Ellmana. Stężenia ACR i SN (III) w modelu ex vivo odpowiadały ich dziennemu spożyciu (odpowiednio DIA - daily intake of acrylamide - i DIN - daily intake of sodium nitrates (V) i (III)), oszacowanemu na podstawie kwestionariusza żywieniowego.

WYNIKI: W obu modelach akrylamid i azotany spowodowały znaczny spadek stężenia grup SH, ale ACR spowodował silniejsze zmiany. Kobiety spożywały większą ilość związków zawierających azot w porównaniu z mężczyznami, prawdopodobnie z powodu odmiennych nawyków żywieniowych.

WNIOSKI: Uzyskane wyniki wskazują, że ksenobiotyki zawierające azot są ważnymi czynnikami obniżającymi potencjał antyoksydacyjny osocza, a ich spożycie powinno być kontrolowane.

\section{SŁOWA KLUCZOWE}

akrylamid, azotan (III) i (V) sodu, dzienne spożycie, grupy tiolowe, potencjał antyoksydacyjny

\section{INTRODUCTION}

The antioxidant properties of human blood plasma are guaranteed by various enzymatic or non-enzymatic biological compounds. Thiol groups ( $\mathrm{SH}$ ) form one of the important elements in the mechanism of antioxidant defense, as they are strong reductors, which easily undergo oxidation to disulfide bonds, nitrosothiols or sulfinic acids [1]. The main source of thiol groups in blood plasma is primarily glutathione, and in smaller amounts, cysteine residues of albumin. Glutathione helps in the maintenance of SH groups of albumin in the reduced state, which prevents their irreversible oxidation during oxidative stress (OS) $[2,3,4]$. The measurement of total $\mathrm{SH}$ concentration reflects the antioxidant capacity of blood plasma, but it is also a good indicator of oxidative damage to proteins in different diseases such as diabetes mellitus, metabolic syndrome, cancers, fertility disorders and others. Additionally it is applied as a marker of exposure to certain xenobiotics $[1,5,6,7]$. Estimating the biochemical and health effects of exposure to different xenobiotics is very important but relatively difficult due to chronic exposure, the low, often subminimal concentrations of xenobiotics, and their different sources as well as their multi-faceted mechanisms of action $[8,9]$. Currently, increasing attention is being paid to dietary compounds, both natural ones and those added to food as preservatives, flavor enhancers or dyes. A proper choice of diet is particularly significant during the growth and development of children and adolescents $[10,11]$. The knowledge of dietary habits in certain social groups can be helpful in estimating the health hazards connected with dietary xenobiotics and the subsequent introduction of appropriate preventive actions before harmful contaminant-induced effects [12].

Special attention is given to the adverse action of nitrogen-containing compounds commonly occurring in food such as nitrates and acrylamide. Due to their common occurrence in food, they are often taken with the daily diet. These compounds, as well as products of their biotransformation (such as nitrosamines and glycidamide), are considered potentially harmful for human health, however, the evidence of adverse effects caused by their increased dietary intakes is weak. The research on their effects on the human body is currently significant in relation to civilizational threats. It is indicated that they may induce OS and disturb the oxidative/ /antioxidative balance, thus participating in the pathogenesis of many diseases $[13,14,15]$. Sodium nitrate (V) and sodium nitrate (III), abbreviated as $\mathrm{SN}$, are widely used as fertilizers and food preservatives. Approximately $25 \%$ of supplied $\mathrm{SN}(\mathrm{V})$ is reduced to $\mathrm{SN}$ (III), which is definitely much more toxic and causes the formation of procarcinogenic nitrosamines, with potential free radical properties available to damage $\mathrm{SH}$ groups $[15,16]$. The literature data also confirm the toxicity of acrylamide (ACR), which is formed during the thermal processing of food and its metabolites. Tobacco smoke is another major source of ACR [17,18]. In the organism, ACR undergoes metabolic conversion to its reactive epoxide form - glycidamide. This compound demonstrates the ability to form adducts with proteins, mainly hemoglobin, which can lead to disturbances in their structure and function. Furthermore, glycidamide, through binding to DNA, may trigger damage to genetic material $[19,20]$.

Evaluation of the parameters of the plasma antioxidant system is the subject of constant attention. It is known that the antioxidant capacity changes under exposure to various xenobiotics, as well as those derived from foods [21]. The general toxic effects of ACR and SN (V) and (III), and nutritional questionnaires on the intake of these substances in the diet are relatively numerous and well-known [20,22,23,24], but there is still a lack of data evaluating the impact of these compounds on the total cellular pool of free thiols in blood plasma.

The aim of this study was to estimate the influence of ACR and SN (V) and (III), derived from the diet, on the total pool of free thiols in blood plasma in young healthy people. We decided to measure the concentrations of the SH groups in blood plasma under in vivo conditions and in an ex vivo model after incubation with ACR and SN concentrations estimated on the basis of a nutritional questionnaire, corresponding to the average daily intake of the studied population. Such conditions are intended to reflect the chronic exposure to low concentrations of these compounds and to estimate possible time-dependent changes in $\mathrm{SH}$ group levels. 


\section{MATERIAL AND METHODS}

\section{General characteristics}

One hundred healthy young people, aged 19-24, students of Wroclaw Medical University, were recruited for this study. The exclusion criteria included serious diseases, metabolic disorders, mental health issues and declared regular use of medication. Of the participants that were recruited, 34 were excluded from the study (18 participants did not correctly complete the nutritional questionnaire, 9 declared particular dietary habits, such as vegetarianism or gluten-free diets and 7 declared taking dietary supplements including antioxidants). Moreover, 4 blood samples had to be excluded because of hemolysis. Finally, the study involved 62 young healthy people, 22 men (35.5\%) and 40 women $(64.5 \%)$. Blood was collected from all of them in a fasting tate and placed into test tubes containing EDTA-K, After centrifugation under standard conditions, the obtained plasma was stored at $-80^{\circ} \mathrm{C}$ until used (for no longer than 2 months). Before the blood was drawn, each of the study participants completed the nutritional questionnaire. The study was approved by the Bioethics Committee of the Wroclaw Medical University KB-26/2016. Participation in the study was anonymous and voluntary.

\section{Nutritional questionnaire}

The nutritional questionnaire was prepared on the basis of a dietary habits questionnaire (DHQ) developed and validated at the Department of Food Science and Dietetics of Wroclaw Medical University [25]. It consists of 32 questions, including general ones about gender, age, height, weight and smoking habits, and detailed ones (27 questions) relating to the amount of food consumed, which was used to estimate daily intakes of ACR and SN (V) and (III) on the basis of the "Album of photographs of food products and dishes" published by the National Food and Nutrition Institute in Warsaw, containing photos of various standard portions (corresponding to weights of the individual products) of different dishes [26,27]. Furthermore, the questionnaire included questions about the means of food preparation because this might affect the total amount of the examined nitrogen-containing compounds in food.

\section{Daily intake calculation}

Based on the results of the nutritional questionnaire and the literature data for the Polish population, the daily intake of acrylamide (DIA) and daily intake of sodium nitrates (V) and (III) (DIN) from the diet were calculated $[28,29,30,31]$. The DIA and DIN per $\mathrm{kg}$ of body weight of the examined young people $[\mu \mathrm{g} / \mathrm{kg}$ bw/day] was calculated using the following equations: DIA = $\mathrm{ACR} \times \mathrm{W} \times \mathrm{R} / \mathrm{M}$, and $\mathrm{DIN}=\mathrm{SN} \times \mathrm{W} \times \mathrm{R} / \mathrm{M}$, respectively, where: $\mathrm{ACR}=$ average content of acrylamide in the products indicated by the respondents $[\mu \mathrm{g} / \mathrm{kg}$ of product], $\mathrm{SN}=$ average content of sodium nitrates $(\mathrm{V})$ and (III) in the products indicated by the respondents $[\mu \mathrm{g} / \mathrm{kg}$ of product], $\mathrm{W}=$ weight of the product $[\mathrm{kg}]$, $\mathrm{R}=$ frequency of consumption per day, and $\mathrm{M}=$ body mass of the participant $[\mathrm{kg}]$.

\section{Measurement of SH group concentrations in in vivo and ex vivo models}

To evaluate the changes in the $\mathrm{SH}$ group levels as a result of exposure to ACR and SN (V) and (III), we conducted measurements in two experimental models: under in vivo and ex vivo conditions. The first model (in vivo) evaluates the $\mathrm{SH}$ group concentrations in the context of nitrogen-containing compound intakes from the diet by the participants under native conditions (time $t_{0}$ ). The second one evaluated the effect of certain doses of the nitrogen-containing compounds on the $\mathrm{SH}$ levels, after exposure to these compounds ex vivo. The samples of blood plasma were incubated separately with a solution of ACR at the concentration of $1.2 \mu \mathrm{M}$ (estimated on the basis of DIA) and with SN (III) at the concentration of $0.56 \mathrm{mg} / 1$ (estimated on the basis of DIN) for 1 hour $\left(t_{1}\right)$ at the temperature of $37^{\circ} \mathrm{C}$ on a Heidolph Polymax 1040 (Germany) platform. We applied only SN (III), due to the fact that SN (V) is rapidly converted in the organism into the more reactive and toxic SN (III) [15]. The concentration of SH groups (in both models) was measured spectrophotometrically using Ellman's method as described elsewhere [32].

\section{Measurement of protein concentration}

The total blood plasma protein concentration $(\mathrm{g} / \mathrm{L})$ was measured using the spectrophotometric method, based on the ability of amino acids to absorb ultraviolet radiation at two specific wavelengths $(\lambda=280$ and $\lambda=260 \mathrm{~nm}$ ) [33]. This enables the concentration of SH groups to be presented as $\mu \mathrm{mol} / \mathrm{g}$ of protein.

\section{Statistical analysis}

Statistical analysis was performed using the Statistica PL program, version 12. The results are shown in the tables as average values and standard deviation, median and first and third quartile (quantitative date), as well as as a percentage (qualitative data). The normality of distribution was checked by the Shapiro-Wilk test. The significance of differences between the compared groups was evaluated using the U Mann-Whitney or Wilcoxon test. Spearman's rank order correlation was conducted. The statistical significance was set at $\mathrm{p}<0.05$.

\section{RESULTS}

The results of the analysis of the nutritional questionnaire data on the DIA and DIN by the participants of this study, per $\mathrm{kg}$ of body weight ( $\mu \mathrm{g} / \mathrm{kg}$ bw/day), taking gender into account, are shown in Table I. 


\begin{tabular}{|c|c|c|c|}
\hline \multirow{2}{*}{ Parameter } & $\begin{array}{c}\text { Total } \\
(n=62)\end{array}$ & $\begin{array}{l}\text { Women (W) } \\
(n=40)\end{array}$ & $\begin{array}{l}\text { Men (M) } \\
(n=22)\end{array}$ \\
\hline & \multicolumn{3}{|c|}{ DIA } \\
\hline Mean \pm Stand. deviation & $1.069 \pm 1.038$ & $1.163 \pm 1.047$ & $0.647 \pm 0.301$ \\
\hline $\begin{array}{l}\text { Median } \\
1 Q-3 Q\end{array}$ & $\begin{array}{c}0.692 \\
0.429-1.140\end{array}$ & $\begin{array}{c}1.123 \\
0.429-1.209\end{array}$ & $\begin{array}{c}0.647 \\
0.482-0.683\end{array}$ \\
\hline \multirow[t]{2}{*}{ Statistical significance $\mathrm{M}$ vs $\mathrm{W}$} & $p=0.3247$ & & \\
\hline & \multicolumn{3}{|c|}{ DIN } \\
\hline Mean \pm Stand. deviation & $0.625 \pm 0.107$ & $0.664 \pm 1.145$ & $0.451 \pm 0.595$ \\
\hline $\begin{array}{l}\text { Median } \\
1 Q-3 Q\end{array}$ & $\begin{array}{c}0.242 \\
0.136-0.680\end{array}$ & $\begin{array}{c}0.264 \\
0.136-0.681\end{array}$ & $\begin{array}{c}0.216 \\
0.188-0.363\end{array}$ \\
\hline Statistical significance $M$ vs $W$ & $p=0.7427$ & & \\
\hline
\end{tabular}

Some differences in the amount of ACR and SN (III) and $(\mathrm{V})$ consumed with food by each sex were observed. Generally the DIA and DIN values for women were higher compared to those in men (about $44 \%$ and $32 \%$, respectively), but without statistical significance. In the assessment of exposure to ACR derived from food, ACR contained in tobacco smoke was also taken into account, however, only $14 \%$ of respondents reported a smoking habit. There were no significant differences in the values of DIA and DIN between the smokers and non-smokers, which is probably associated with the relatively short period of cigarette smoking reported by the respondents; therefore this exposure was not included in further analysis of the obtained results. The percentage of participation of food products containing ACR and SN (V) and (III) in the daily diet (based on the results of the nutritional questionnaire) is shown in Figure 1.

The analysis of the percentage of ACR intake in daily consumption as indicated by the respondents demonstrated that the largest contribution to the supply of ACR was made by French fries (about 30\%). The second major sources were crackers and biscuits, followed by chips and gingerbread (Figure 1A). The most important source of consumed SN (V) and (III) in the participants' diet was beetroot and lettuce, which accounted for $35 \%$ and $33 \%$, respectively (Figure 1B).

The results of measurements of $\mathrm{SH}$ group concentrations in blood plasma collected in the fasting state (time to) from the participants (in vivo model) as well as after a 1-hour incubation (time $t_{1}$ ) with appropriate concentrations of ACR and SN (III), together with statistical analysis, are given in Table II.
The one hour incubation (time $t_{1}$ ) of blood plasma with appropriate concentrations of ACR and SN (III) showed that both xenobiotics induced a significant decrease ( $p<0.05$ and $p<0.001$, respectively) in the concentrations of SH groups, compared to their initial concentration (time to). Sodium nitrate (III) triggers a minor decrease in the concentration of $\mathrm{SH}$ groups, compared to that induced by ACR, about $14 \%$ and $57 \%$, respectively. The difference in the reduction of $\mathrm{SH}$ groups by ACR and $\mathrm{SN}$ was also statistically significant $(p<0.001)$. The calculation of the obtained results per gram of total protein (average concentration of protein in the whole group was $51.52 \mathrm{~g} / \mathrm{L}$ ) did not alter the statistical significance of the observed differences. In Figure 2, the tendency of SH groups to reduction, as measured in the blood plasma in an ex vivo model (time $t_{1}$ ) relative to their native concentration (in vivo model - time to) and expressed as a percentage of reduction of $\mathrm{SH}$ groups, is shown graphically.

When estimating the correlation between the concentration of SH groups (expressed as per gram of the total protein) measured in the blood plasma of the same patients in in vivo and in the ex vivo models, we revealed a statistically significant $(\mathrm{p}<0.005)$, positive, high correlation, between the analyzed variables: $\mathrm{SH}$ to vs SH ACR $t_{1}(r=0.4714), S H$ to vs SH SN t $t_{1}(r=0.7019)$ and $\mathrm{SH} A C R \mathrm{t}_{1}$ vs $\mathrm{SH} S N \mathrm{t}_{1}(\mathrm{r}=0.7038)$. However, analysis of the correlation between the concentration of SH groups measured in the samples of native blood plasma collected from the participants ( $\mathrm{t}_{0}$ ) and the DIA and DIN by the surveyed students did not show a simple, direct, statistically significant relationship between these variables (data not shown). 


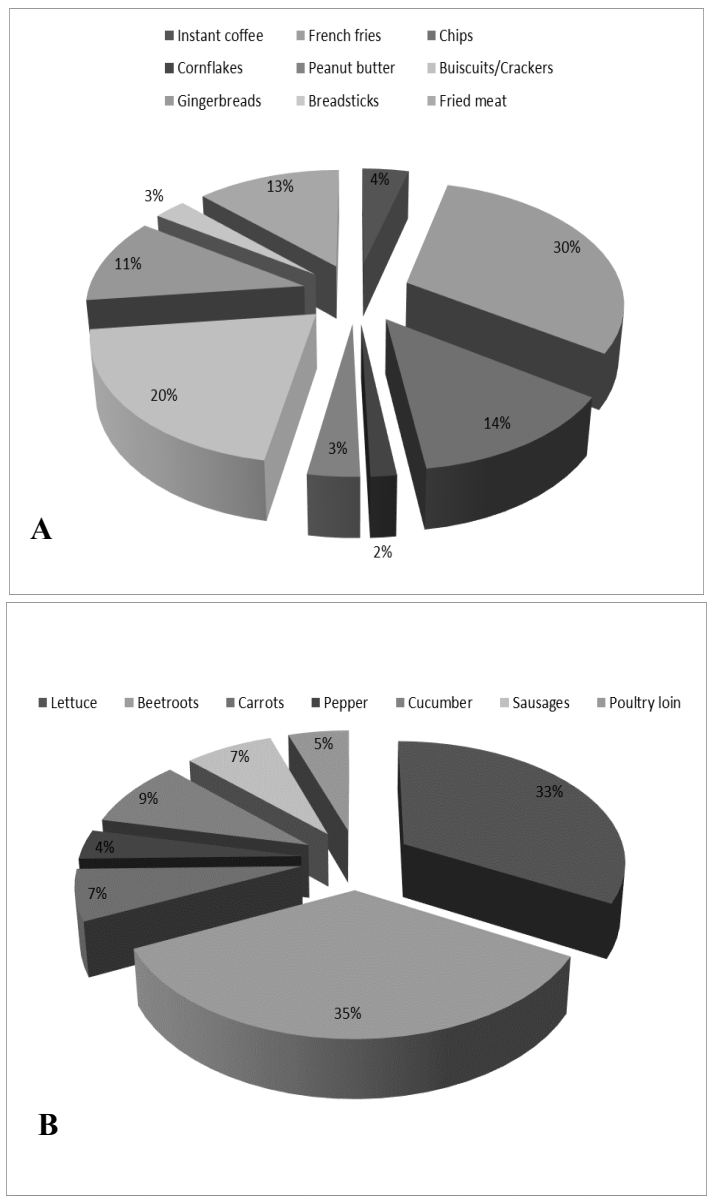

Fig. 1. Sources of acrylamide (A) and sodium nitrate $(V)$ and (III) (B) in daily diet as percentage calculated on basis of nutritional questionnaire. Ryc. 1. Procentowy udział pokarmowych źródeł akrylamidu (A) oraz azotanów (V) i (III) sodu (B) obliczony na podstawie ankiety żywieniowej.

Table II. Concentration of thiol groups under in vivo $\left(\mathrm{t}_{0}\right)$ conditions and after incubation with acrylamide and sodium nitrate (III) in $\mathrm{t}_{1}$ (ex vivo model) Tabela II. Stężenie grup tiolowych w warunkach in vivo $\left(\mathrm{t}_{0}\right)$ i po inkubacji z akrylamidem oraz azotanem (III) sodu w czasie $\mathrm{t}_{1}$ (model ex vivo)

\begin{tabular}{|c|c|c|c|}
\hline \multirow{3}{*}{ Parameter } & \multirow{2}{*}{$\begin{array}{c}\text { in vivo model } \\
\mathrm{SH} \mathrm{t}_{0}\end{array}$} & \multicolumn{2}{|c|}{ ex vivo model } \\
\hline & & SH ACR $\mathrm{t}_{1}$ & $\mathrm{SH} \mathrm{SN} \mathrm{t_{1 }}$ \\
\hline & \multicolumn{3}{|c|}{ Concentration units [mmol/L] } \\
\hline Mean \pm Stand. deviation & $0.506 \pm 0.210$ & $0.242 \pm 0.046$ & $0.438 \pm 0.048$ \\
\hline $\begin{array}{l}\text { Median } \\
1 Q-3 Q\end{array}$ & $\begin{array}{c}0.565 \\
0.514-0.611\end{array}$ & $\begin{array}{c}0.212 \\
0.181-0.239\end{array}$ & $\begin{array}{c}0.432 \\
0.409-0.465\end{array}$ \\
\hline Statistical significance cor & $\mathrm{SH} S N t_{1}$ to $\mathrm{SH}$ to & $p<0.001$ & $p=0.0213$ \\
\hline \multicolumn{2}{|c|}{ Statistical significance between $\mathrm{SH} \mathrm{ACR} \mathrm{t}_{1}$ and $\mathrm{SH} S \mathrm{~S} \mathrm{t}_{1}$} & \multicolumn{2}{|c|}{$p<0.001$} \\
\hline \multicolumn{4}{|c|}{ Concentration units [ $\mu \mathrm{mol} / \mathrm{g}$ protein] } \\
\hline Mean \pm Stand. deviation & $13.351 \pm 5.161$ & $5.662 \pm 3.949$ & $10.024 \pm 1.899$ \\
\hline $\begin{array}{l}\text { Median } \\
1 Q-3 Q\end{array}$ & $\begin{array}{c}12.889 \\
11.121-14.747\end{array}$ & $\begin{array}{c}4.741 \\
3.865-5.678\end{array}$ & $\begin{array}{c}9.733 \\
8.953-10.748\end{array}$ \\
\hline \multicolumn{2}{|c|}{ Statistical significance compared $S H A C R t_{1}$ and $S H S N t_{1}$ to $S H$ to } & $p<0.001$ & $p=0.0269$ \\
\hline \multicolumn{2}{|c|}{ Statistical significance between SH ACR $\mathrm{t}_{1}$ and $\mathrm{SH} S \mathrm{SN} \mathrm{t}_{1}$} & \multicolumn{2}{|c|}{$p<0.001$} \\
\hline
\end{tabular}

$\mathrm{SH} \mathrm{t}_{0}$ - concentration of thiol groups in fasting blood plasma; SH ACR $\mathrm{t}_{1}$ - concentration of thiol groups after an hour of incubation with solution of acrylamide; $\mathrm{SH} \mathrm{SN} \mathrm{t}_{1}$ - concentration of thiol groups after an hour of incubation with solution of sodium nitrate (III). 


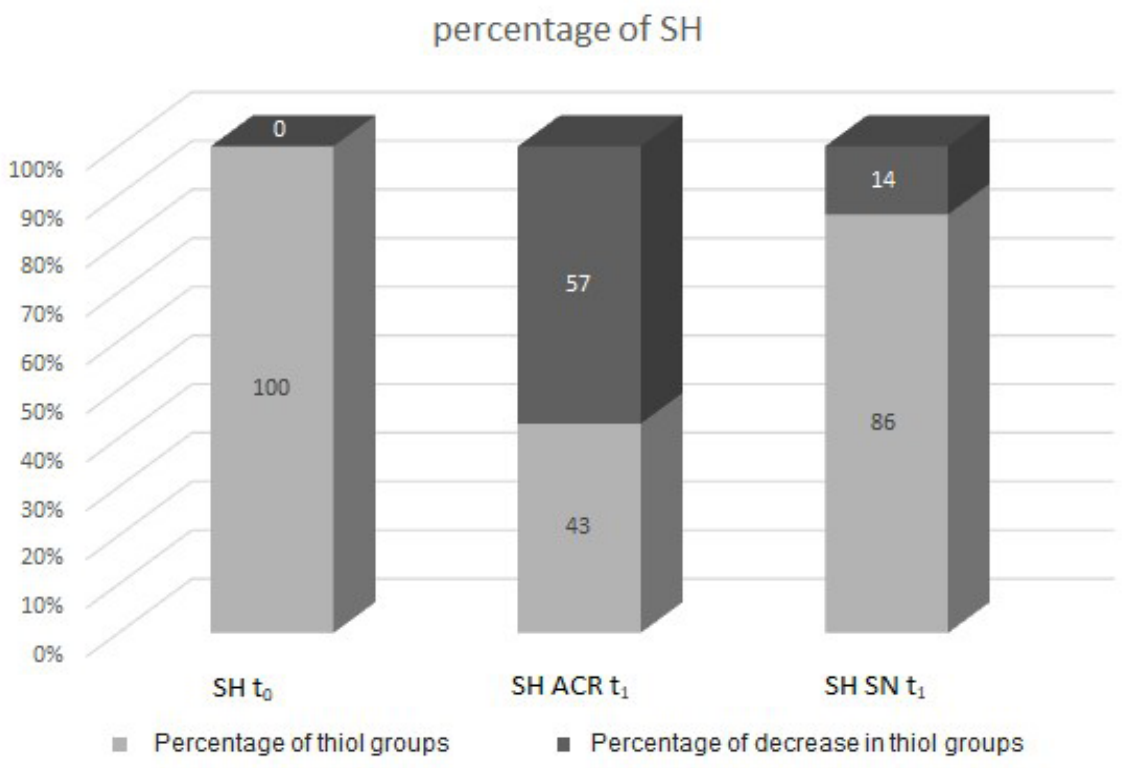

Fig. 2. Comparison of percentage of reductions in thiol (SH) group concentrations after incubation with solutions of acrylamide (ACR) and sodium nitrate (SN) (III) at time $t_{1}$ in relation to time to.

Ryc. 2. Procentowy spadek stężenia grup tiolowych (SH) po inkubacji z akrylamidem (ACR) oraz azotanem (III) sodu (SN).

\section{DISCUSSION}

The adverse effect of exposure to nitrogen-containing compounds such as ACR and SN is well known [16,19], but not in the aspect of their influence on SH group concentrations, which may result in loss of the antioxidant properties of blood plasma. The thiol groups play an important role in maintaining homeostasis, acting as an important element of the antioxidant defense of organisms, being components of low molecular weight antioxidants (e.g. glutathione, cysteine, homocysteine), as well as high molecular weight antioxidants (e.g. blood albumin). The measurement of $\mathrm{SH}$ concentrations is also used in scientific research to evaluate the oxidative damage of proteins in a variety of pathological conditions $[34,35]$.

Both ACR and SN (V) and (III) are present in many food products, and the thermal processing of food increases the content of these compounds [20,24,36]. Although SN (V) and (III) are used in the food industry as preservatives (antioxidants), represented by the symbols E251 and E250, respectively [37], their contribution to the intensification of OS is also indicated [38]. Acrylamide may form adducts with biological compounds containing SH groups, especially with proteins, e.g. hemoglobin, or glutathione $[39,40]$. In this aspect, the measurement of concentrations of the SH group as a marker reflecting the loss of plasma antioxidant properties resulting from exposure to selected xenobiotics is highly reasonable and interesting.
We observed that the daily intake of ACR and SN (V) and (III) by the respondents, as estimated by the nutritional questionnaire, does not exceed the range of acceptable values for these compounds. To date there is still no acceptable daily intake for ACR [41], however, the average DIA did not exceed the values accepted for ACR, which is the benchmark dose lower confidence limit $\left(\mathrm{BMDL}_{10}\right)$ of $0.17 \mathrm{mg} / \mathrm{kg}$ bw/day for carcinogenesis and $0.43 \mathrm{mg} / \mathrm{kg}$ bw/day for neurotoxicity, as determined by the European Food Safety Authority (EFSA) [42]. The DIN values do not exceed the established acceptable daily intake of SN (V) $(5.07 \mathrm{mg} / \mathrm{kg}$ bw/day) or SN (III) $(0.1 \mathrm{mg} / \mathrm{kg}$ bw/day) [38]. A greater amount of these nitrogen-containing compounds in the daily diet was consumed by women, which suggests slightly different dietary habits or different sources of these xenobiotics for this group. The DIA and/or DIN values we estimated for the examined young people were higher, or similar to the values specified for other populations [38,42,43]. Malczyk et al. [44] estimated the average DIA as $0.49 \mathrm{mg} / \mathrm{kg}$ bw/day for students of secondary schools in Nysa, Poland, aged 15-19 years. Other researchers in European populations (Germans, Danes and Swedes as well as Poles) in different age groups (from 25 to 78 years old), reported these values as $0.48-4.93 \mathrm{mg} / \mathrm{kg}$ bw/day $[22,30,43,45]$.

In the studied group of young people, the plasma concentrations of $\mathrm{SH}$ groups in native conditions ( $\left.\mathrm{t}_{0}\right)$ were mostly (almost 86\%) within the ranges indicated in the scientific literature, i.e. $0.46-0.78 \mathrm{mmol} / \mathrm{L}[46,47]$. 
Although a decline below this range was observed in only $14 \%$ of the respondents, this suggests that the impact of these nitrogen-containing compounds on the blood plasma antioxidant potential is not neutral and cannot be ignored. It is necessary to continue this research on a larger population due to the adverse effect of xenobiotics and their intake in the daily diet. Interestingly, the smoking habits of the respondents did not affect the concentration of $\mathrm{SH}$ groups, probably due to the occasional, short periods of cigarette smoking declared by the respondents.

The adverse effects of ACR and SN (III) on the SH groups were confirmed in the ex vivo model, where 1 hour of exposure of plasma to these xenobiotics caused a significant decrease in SH groups in plasma. This incubation time was selected due to the biotransformation of the examined compounds and their relatively short presence in the organism $[48,49,50]$. The time-dependent reduction of plasma antioxidant potential is also confirmed by the significant correlation between the $\mathrm{SH}$ concentration under in vivo $\left(\mathrm{t}_{0}\right)$ and ex vivo $\left(\mathrm{t}_{1}\right)$ conditions. In the scientific literature there is a lack of data focusing on $\mathrm{SH}$ concentrations with regard to the influence of nitrogen-containing compounds derived from food. Both ACR and SN (V) and (III) are reactive compounds, which can induce and/or intensify OS by the formation of reactive forms of oxygen and nitrogen, which are strong electrophiles and react readily with the $\mathrm{SH}$ groups of biological compounds in plasma. We demonstrated stronger adverse effects induced by ACR on the SH groups, which may result from the presence of multiple binding with electrophilic properties in the ACR molecule, which determines its greater reactivity with $\mathrm{SH}$ groups of proteins [51,52]. The increase in intensity of OS in the presence of ACR is also associated with an increase in the reactive oxygen species, and a decrease in the activity of superoxide dismutase and the concentration of reduced glutathione [20,53]. On the other hand, it is reported that nitrates may also have a positive influence on human health as a source of nitric oxide, which is beneficial for maintaining endothelial functions, and performs a useful protective role in the prevention of cardiovascular diseases [54,55].

The negative effects of ACR and SN (V) and (III) on total plasma thiols, resulting in inactivation and reduction of SH group levels, is very disadvantageous for the organism. The oxidation of $\mathrm{SH}$ groups disturbs, among others, the permeability and transport through cell membranes, their stability, and changes in protein structure. In our previous studies using circular di- chroism, we showed that ACR and SN (III) significantly influence the secondary structure of albumin, significantly reducing the alpha-helical content [56]. Furthermore, it can lead to the formation of protein aggregates via disulfide bridges (inside and between proteins). The formed disulfides are more reactive, and may trigger secondary damage through interacting with other macromolecules. Moreover, the modified proteins are more resistant to proteolysis, which consequently leads to an increase in their accumulation in the organism, and the further propagation of systemic disorders $[1,57,58]$.

\section{CONCLUSION}

Although the estimated values of DIA and DIN in the study group of healthy young people did not exceed the permissible values of intake for these compounds described in the literature, the obtained results indicate that consumers should pay special attention to the quantity and frequency of consumption of foods rich in ACR and SN (V) and (III). The presented preliminary results, in both the in vivo and ex vivo models, confirm the adverse effect of these xenobiotics through the loss of antioxidant capacity by diminishing the concentrations of SH groups, especially as a result of ACR action. The obtained results indicate the potential usefulness of $\mathrm{SH}$ group measurements in blood plasma as indicators of exposure to these nitrogen-containing compounds, but due to their preliminary character, further analysis on larger groups of participants is needed. It will be helpful in introducing appropriate preventive actions regarding intakes of ACR and SN (V) and (III) in the diet, especially in certain social groups, with specific dietary habits and lifestyles, such as students.

\section{Conflict of interest}

The authors do not declare any conflicts of interest.

\section{Funding sources}

This research was supported by the statutory activities of Wroclaw Medical University [number ST-985].

\section{Acknowledgments}

The authors thank Dr. Anna Prescha, from the Department of Bromatology and Dietetics, Faculty of Pharmacy, Wroclaw Medical University, for consultation during construction of the nutritional questionnaire. 


\section{Author's contribution}

Study design - A. Piwowar

Data collection - A. Rorbach-Dolata, Z. Marchewka

Data interpretation - E. Żurawska-Plaksej, A. Piwowar

Statistical analysis - A. Rorbach-Dolata

Manuscript preparation - A. Piwowar, E. Żurawska-Płaksej

Literature research -A. Rorbach-Dolata, Z. Marchewka

\section{REFERENCES}

1. Prakash M., Shetty M.S., Tilak P., Anwar N. Total Thiols: Biomedical importance and their alteration in various disorders. Online J. Health Allied Sci. 2009; 8(2): 1-9.

2. Ha C.E., Bhagavan N.V. Novel insights into the pleiotropic effects of human serum albumin in health and disease. Biochim. Biophys. Acta 2013; 1830(12): 5486-5493, doi: 10.1016/j.bbagen.2013.04.012.

3. Winther J.R., Thorpe C. Quantification of Thiols and Disulfides. Biochim Biophys. Acta 2014; 1840(2): 838-846, doi: 10.1016/j.bbagen.2013.03.031.

4. Kawakami A., Kubota K., Yamada N., Tagami U., Takehana K., Sonaka I., Suzuki E., Hirayama K. Identification and characterization of oxidized human serum albumin: A slight structural change impairs its ligand-binding and antioxidant functions. FEBS J. 2006; 273(14): 3346-3357.

5. Yu T., Robotham J.L., Yoon Y. Increased production of reactive oxygen species in hyperglycemic conditions requires dynamic change of mitochondria morphology. Proc. Natl. Acad. Sci. USA 2006; 103(8): 2653-2658.

6. Żurawska-Płaksej E., Grzebyk E., Marciniak D., Szymańska-Chabowska A., Piwowar A. Oxidatively modified forms of albumin in patients with risk factors of metabolic syndrome. J. Endocrinol. Invest. 2014; 37(9): 819-827, doi: 10.1007/s40618-014-0111-8

7. Sawicka E., Kratz E.M., Szymańska B., Guzik A., Wesołowski A., Kowal P., Pawlik-Sobecka L., Piwowar A. Preliminary Study on Selected Markers of Oxidative Stress, Inflammation and Angiogenesis in Patients with Bladder Cancer Pathol. Oncol. Res. 2019, doi: 10.1007/s12253-019-00620-5.

8. O'Brien J., Renwick A.G., Constable A., Dybing E., Müller D.J., Schlatter J., Slob W., Tueting W., van Benthem J., Williams G.M., Wolfreys A. Approaches to the risk assessment of genotoxic carcinogens in food: A critical appraisal. Food Chem. Toxicol. 2006; 44(10): 1613-1635.

9. Lesser S., Pauly L., Volkert D., Stehle P. Nutritional situation of the elderly in Eastern/Baltic and Central/Western Europe - the AgeingNutrition project. Ann. Nutr. Metab. 2008; 52 Suppl 1: 62-71, doi: 10.1159/000115353.

10. Phuong T.B., Huong N.T., Tien T.Q., Chi H.K., Dunne M.P. Factors associated with health risk behavior among school children in urban Vietnam. Glob. Health Action 2013; 6: 1-9, doi: 10.3402/gha.v6i0.18876.

11. Visioli F. Xenobiotics and human health: A new view of their pharma-nutritional role. Pharma Nutrition 2015; 3(2): 60-64

12. Wu J.C., Lai C.S., Tsai M.L., Ho C.T., Wang Y.J., Pan M.H. Chemopreventive effect of natural dietary compounds on xenobiotic-induced toxicity. J. Food Drug Anal. 2017; 25(1): 176-186, doi: 10.1016/j.jfda.2016.10.019.

13. Davies K.J. Oxidative Stress, Antioxidant Defenses, and Damage Removal, Repair, and Replacement Systems. IUBMB Life 2000; 50(4-5): 279-289.

14. Kerley C.P. Dietary nitrate as modulator of physical performance and cardiovascular health. Curr. Opin. Clin. Nutr. Metab. Care 2017; 20(6): 440-446, doi: 10.1097/MCO.0000000000000414.

15. Semla M., Goc Z., Martiniaková M., Omelka R., Formicki G. Acrylamide: a common food toxin related to physiological functions and health. Physiol. Res. 2017; 66(2): 205-217.

16. Habermeyer M., Roth A., Guth S., Diel P., Engel K.H., Epe B., Fürst P., Heinz V., Humpf H.U., Joost H.G., Knorr D. et al. Nitrate and nitrite in the diet: How to assess their benefit and risk for human health. Mol. Nutr. Food Res. 2015; 59(1): 106-128, doi: 10.1002/mnfr.201400286.

17. Lingnert H., Grivas S., Jägerstad M., Skog K., Törnqvist M., Åman P. Acrylamide in food: mechanisms of formation and influencing factors during heating of foods. Scand. J. Nutr. 2002; 46(4): 159-172.

18. Stadler R.H., Scholz G. Acrylamide: an update on current knowledge in analysis, levels in food, mechanisms of formation, and potential strategies of control. Nutr. Rev. 2004; 62(12): 449-467.

19. Carere A. Genotoxicity and carcinogenicity of acrylamide: a critical review. Ann. Ist. Super. Sanita 2006; 42(2): 144-155.

20. Li D., Wang P., Liu Y., Hu X., Chen F. Metabolism of Acrylamide: Interindividual and Interspecies Differences as Well as the Application as Biomarkers. Curr. Drug Metab. 2016; 17(4): 317-326.

21. Hydzik P., Krośniak M., Francik R., Gomółka E., Ebru E.D., Zagrodzki P. Serum antioxidant parameters in patients poisoned by different xenobiotics. Acta Pol. Pharm. 2016; 73(2): 337-344.

22. Wilson K.M., Bälter K., Adami H.O., Grönberg H., Vikström A.C., Paulsson B., Törnqvist M., Mucci L.A. Acrylamide exposure measured by food fre- quency questionnaire and hemoglobin adduct levels and prostate cancer risk in the Cancer of the Prostate in Sweden Study. Int. J. Cancer 2009; 124(10): 2384-2390, doi: 10.1002/ijc.24175.

23. Babateen A.M., Fornelli G., Donini L.M., Mathers J.C., Siervo M. Assessment of dietary nitrate intake in humans: a systematic review. Am. J. Clin. Nutr. 2018; 108(4): 878-888, doi: 10.1093/ajcn/nqy108.

24. Hakeem K.R., Sabir M., Ozturk M., Akhtar M.S., Ibrahim F.H., Ashraf M., Ahmad M.S.A. Nitrate and Nitrogen Oxides: Sources, Health Effects and Their Remediation. Rev. Environ. Contam. Toxicol. 2017; 242: 183-217, doi: $10.1007 / 398201611$.

25. Ilow R., Królicka O., Regulska-Ilow B., Pluta J. Validation of a food frequency questionnaire for dietary intake estimation among students from Wroclaw. Bromat. Chem. Toksykol. 2005; 38: 313-320.

26. Szponar L., Wolnicka K., Rychlik E. Album of photographs of food products and dishes. National Food and Nutrition Institute. Warszawa 2000

27. Grochowska-Niedworok E., Rydelek J., Całyniuk B., Misiarz M., Kisvetrova $\mathrm{H}$. Estimating portion size of selected foods based on photograpy. Probl. Hig. Epidemiol. 2014; 95(3): 696-700.

28. Anyzewska A., Wawrzyniak A. Evaluating adult dietary intakes of nitrate and nitrite in Polish households during 2006-2012. Rocz. Panstw. Zakl. Hig. 2014; 65: 107-111

29. Guidance for Industry: Estimating Dietary Intake of Substances in Food 2006 [online] https://www.fda.gov/regulatory-information/search-fda-guidance-documents/guidance-industry-estimating-dietary-intake-substances-food [accessed August 6, 2019].

30. Bekas W., Kowalska D., Łobacz M., Kowalski B. Dietary acrylamide intake by representatives of selected group of white collar workers. Bromat. Chem. Toksykol. 2009; 42: 491-497.

31. Wawrzyniak A., Hamułka J., Skibińska E. Evaluation of nitrate, nitrite and antioxidant vitamins intake in daily food rations of children aged 1-6 years. Rocz. Panstw. Zakl. Hig. 2003; 54: 65-72.

32. Rice-Evans C.A., Diplock A.T., Symons M.C.R. Techniques in free radical research. Elsevier Science. New York, Tokyo 1991: 207-230.

33. Aitken A., Learmonth M. Protein Determination by UV Absorption. In: The Protein Protocols Handbook. Ed.: J.M. Walker. Humana Press. Totowa, UK 2002.

34. Vural G., Gümüsyayla S., Deniz O., Neșelioğlu S., Erel Ö. Relationship between thiol-disulphide homeostasis and visual evoked potentials in patients with multiple sclerosis. Neurol. Sci. 2019; 40(2): 385-391, doi: 10.1007/ s10072-018-3660-3.

35. Davies M.J., Fu S., Wang H., Dean R.T. Stable markers of oxidant damage to proteins and their application in the study of human disease. Free Radic. Biol. Med. 1999; 27(11-12): 1151-1163.

36. Keramat J., LeBail A., Prost C., Jafari M. Acrylamide in Baking Products: A Review Article. Food Bioprocess Technol. 2011; 4: 530-543

37. PubChem Compound Database. U.S. National Library of Medicine. National Center for Biotechnology Information [online] https://pubchem.ncbi.nlm. nih.gov/compound/24268\#section=To [accessed August 6, 2019].

38. Hord N.G., Tang Y., Bryan N.S. Food sources of nitrates and nitrites: the physiologic context for potential health benefits. Am. J. Clin. Nutr. 2009; 90(1): 1-10, doi: 10.3945/ajen.2008.27131.

39. Tong G.C., Cornwell W.K., Means G.E. Reactions of acrylamide with glutathione and serum albumin. Toxicol. Lett. 2004; 147(2): 127-131.

40. Xu Y., Cui B., Ran R., Liu Y., Chen H., Kai G., Shi J. Risk assessment, formation, and mitigation of dietary acrylamide: current status and future prospects. Food Chem. Toxicol. 2014; 69: 1-12, doi: 10.1016/j.fct.2014.03.037.

41. Mojska H., Gielecińska I., Szponar L., Ołtarzewski M. Estimation of the dietary acrylamide exposure of the Polish population. Food Chem. Toxicol. 2010; 48(8-9): 2090-2096, doi: 10.1016/j.fct.2010.05.009.

42. EFSA's 11th Scientific Colloquium. Acrylamide carcinogenicity: new evidence in relation to dietary exposure. Sci. Colloq. Series 2008; 11: 1-27, doi: 10.2903/sp.efsa.2011.EN-121.

43. Konings E.J., Baars A.J., van Klaveren J.D., Spanjer M.C., Rensen P.M., Hiemstra M., van Kooij J.A., Peters P.W. Acrylamide exposure from foods of the Dutch population and an assessment of the consequent risks. Food Chem. Toxicol. 2003; 41(11): 1569-1579. 
44. Malczyk E., Grochowska-Niedworok E., Wyka J., Misiarz M., Kacprzak M. Evaluation of akrylamid intake diets of secondary school students in Nysa. Bromat. Chem. Toksykol. 2012; 45(3): 685-691.

45. Hilbig A., Freidank N., Kersting M., Wilhelm M., Wittsiepe J. Estimation of the dietary intake of acrylamide by German infants, children and adolescents as calculated from dietary records and available data on acrylamide levels in food groups. Int. J. Hyg. Environ. Health 2004; 207(5): 463-471.

46. Piwowar A., Knapik-Kordecka M., Warwas M. Markers of oxidative protein damage in plasma and urine of type 2 diabetic patients. Br. J. Biomed. Sci. 2009; 66(4): 194-199.

47. Hawkins C.L., Morgan P.E., Davies M.J. Quantification of protein modification by oxidants. Free Radic. Biol. Med. 2009; 46(8): 965-988, doi: 10.1016/j. freeradbiomed.2009.01.007.

48. Hord N.G., Tang Y., Bryan N.S. Food sources of nitrates and nitrites: the physiologic context for potential health benefits. Am. J. Clin. Nutr. 2009; 90(1): 1-10, doi: 10.3945/ajen.2008.27131.

49. Fennell T.R., Sumner S.C., Snyder R.W., Burgess J., Friedman M.A. Kinetics of elimination of urinary metabolites of acrylamide in humans. Toxicol. Sci. 2006; 93(2): 256-267.

50. Wang Y., Townsend M.K., Eliassen A.H., Wu T. Stability and Reproducibility of the Measurement of Plasma Nitrate in Large Epidemiologic Studies. N. Am. J. Med. Sci. (Boston) 2013; 6(2): 82-86.

51. Polimanti R., Carboni C., Baesso I., Piacentini S., Iorio A., De Stefano G.F.,

Fuciarelli M. Genetic variability of glutathione S-transferase enzymes in hu- man populations: functional inter-ethnic differences in detoxification systems. Gene 2013; 512(1): 102-107, doi: 10.1016/j.gene.2012.09.113.

52. Semla M., Goc Z., Martiniaková M., Omelka R., Formicki G. Acrylamide: a common food toxin related to physiological functions and health. Physiol. Res. 2017; 66(2): 205-217.

53. Marković J., Stošić M., Kojić D., Matavulj M. Effects of acrylamide on oxidant/antioxidant parameters and CYP2E1 expression in rat pancreatic endocrine cells. Acta Histochem. 2018; 120(2): 73-83, doi: 10.1016/j.acthis.2017.12.001. 54. Gilchrist M., Winyard P.G., Benjamin N. Dietary nitrate-good or bad? Nitric Oxide 2010; 22(2): 104-109, doi: 10.1016/j.niox.2009.10.005.

55. Bedale W., Sindelar J.J., Milkowski A.L. Dietary nitrate and nitrite: Benefits, risks, and evolving perceptions. Meat Sci. 2016; 120: 85-92, doi: 10.1016/j.meatsci.2016.03.009.

56. Rorbach-Dolata A., Żurawska-Płaksej E., Piwowar A. Quercetin influences BSA alpha-helical structures of native, ACR- and NaNO2-modified BSAs. Acta Pol. Pharm. 2018; 75(6): 1339-1346, doi: 10.32383/appdr/89724.

57. Oettl K., Stauber R.E. Physiological and pathological changes in the redox state of human serum albumin critically influence its binding properties. Br. J. Pharmacol. 2007; 151(5): 580-590.

58. Maciażek-Jurczyk M., Sułkowska A. Spectroscopic analysis of the impact of oxidative stress on the structure of human serum albumin (HSA) in terms of its binding properties. Spectrochim. Acta A Mol. Biomol. Spectrosc. 2015; 136 Pt B: 265-282, doi: 10.1016/j.saa.2014.09.034. 